Summer 2003

\title{
Examining the (Non-)Status of NGOs in International Law
}

\author{
Kerstin Martens \\ University of Bremen, Germany
}

Follow this and additional works at: https://www.repository.law.indiana.edu/ijgls

Part of the International Law Commons

\section{Recommended Citation}

Martens, Kerstin (2003) "Examining the (Non-)Status of NGOs in International Law," Indiana Journal of Global Legal Studies: Vol. 10 : Iss. 2 , Article 1.

Available at: https://www.repository.law.indiana.edu/ijgls/vol10/iss2/1

This Article is brought to you for free and open access by the Law School Journals at Digital Repository @ Maurer Law. It has been accepted for inclusion in Indiana Journal of Global Legal Studies by an authorized editor of Digital Repository @ Maurer Law. For more information, please contact rvaughan@indiana.edu.

\section{$\Psi$}

JEROME HALL LAW LIBRARY

INDIANA UNIVERSITY

Maurer School of Law
Bloomington 


\title{
Examining the (Non-)Status of NGOs in International Law
}

\author{
Kerstin Martens*
}

Non-governmental organizations (NGOs) are increasingly influential players on the international scene. Since the end of the Cold War, NGOs have enjoyed increasingly easy access to, and better possibilities to affect, political processes taking place above the national level. In fact, the increasing intensity of their activities over the last decade demonstrates that they have become an integral part of the procedures and structures of global governance. ${ }^{1}$ Most visibly, the recent protests of anti-globalization activists in Seattle, Gothenburg, Porto Alegre, Davos, Genoa, and many other locations demonstrated the potential of NGOs to influence the proceedings of international negotiations. These protests also clearly revealed NGOs' capacity for mobilizing and networking across borders and in a short period of time. ${ }^{2}$

But NGOs are not always opponents to governmental institutions and do not always challenge their policies. Rather, they are often directly involved in the design of policies and may shape political processes from inside the official arenas. For example, at the United Nations, NGOs are significantly involved in the activities and performances of the intergovernmental organizations (IGOs).

* Ph.D. candidate at the European University Institute in Florence, Italy; research assistant at the University of Bremen, Germany. In my dissertation I analyze the relationship between NGOs and the United Nations. Special thanks to Philip Alston for helpful comments on an earlier draft and to the Union of International Associations for providing useful links and material.

1. The concept of global governance has often been associated with the management of international relations in the post-Cold War era. In particular, multilateral systems of regulations and international intergovernmental organizations establish the structures of governance in the interdependent global system. Unlike the Westphalian model of sovereign states, the concept of global governance emphasizes the absence of any central authority; therefore, it presents a model of "governance without government." See generally Governance Without Government: Order and Change in World Politics (James N. Rosenau \& Ernst-Otto Czempiel eds., 1992).

2. Jackie Smith, Globalizing Resistance: The Battle of Seattle and the Future of Social Movements, 6 Mobilization I (200I); see also Jackie Smith, Transnational Mobilizations Against Global Trade Liberalization: Challenges for Global Institutions, Paper presented at the 2001 Meeting of the International Studies Association, Feb. 23, 2001; Kaisa Eskola \& Felix Kolb, Attac-Globalisierung ist kein Schicksal, in Zivilgesellschaft international-Alte und neue NGOs 199-212 (Christiane Frantz \& Annette Zimmer eds., 2002) [hereinafter Zivilgesellschaft international]. 
They advise U.N. commissions and committees regularly, they work together with U.N. agencies and implement projects for them, or they assist U.N. institutions and provide necessary information. In his Millennium report, SecretaryGeneral Kofi Annan re-emphasized that strengthening the relations between the United Nations and private actors constitutes a priority of his mandate. He seeks "[t]o give full opportunities to non-governmental organizations and other non-state actors to make their indispensable contribution to the [United $\mathrm{Na}$ tions] Organization's work." 3

Despite the increasing involvement of NGOs in the processes and proceedings of global politics and international law, the features and functions of the "new player" NGO have not yet been clearly identified. ${ }^{4}$ Definitions and interpretations of the term NGO vary enormously and can often be misleading or even contradictory. For some, "NGO" simply describes many different types of organizations which are not governmental, including multi-national companies, national liberation groups, and many more. For others, "NGO" is reserved exclusively for private non-profit organizations encouraging higher values within the legal scope of their society. In international law, the term "NGO" is equally confusing in its application. In this paper, I will argue that there is a lack of agreement on NGOs as subjects of international personality. While in many countries domestic legislation for "private associations" serves as a basis for NGO identification and recognition, at the international level, international legal standards to define and regulate the perception of NGOs have not yet been established.

This "non-status" of NGOs in international law may be considered an opportunity for maintaining a variety of voices of civil society in the international sphere. Since the criteria for actor NGOs are not rigorously regulated, various kinds of societal actors may be given the opportunity to contribute to the political process when they would otherwise be excluded. This non-status, however, also creates various problems. Most importantly, in the light of the increasing participation of NGOs in international political processes, the lack of regulation

3. Report of the Secretary General, We the Peoples: The Role of the United Nations in the TwentyFirst Century, U.N. Doc. A/54/2000 (2000) [hereinafter Millenium report].

4. Kerstin Martens, Alte und neue Players-eine Begriffsbestimmung, in Zivilgesellschaft INternational, supra note 2, at 25; see also Kerstin Martens, Mission Impossible? Defining NGOs, 13 Voluntas 271 (2003), abstract available at http://www.jhu.edu/ istr/pubs/voluntas/voll3-3.html. 
raises questions about NGO representativity and legitimacy. ${ }^{5}$ For whom do NGOs actually stand? Who authorizes them to represent what views? Many NGOs, particularly the well-known organizations such as Amnesty International, the WWF, or CARE, can claim to have a large membership or supporters from many parts of the world; many other NGOs are instead simply self-appointed, consisting of only a small group of people (or even a single individual) and representing the opinions of a relatively small number of people.

For the purposes of this study, I will examine the status of NGOs in international law through a historical analysis covering the last century. In Part I of this article, I will describe current NGO involvement in global governance and analyze certain problems resulting from NGOs' lack of status in international law. Then, in Parts II through IV, I will trace back various attempts to codify an international standard for NGOs from 1910 to the present day. In this context, I will take into account the indirect recognition of NGOs that occurs when intergovernmental organizations (the League of Nations and the United Nations) grant them a consultative status. In addition, I will take a closer look at other juridical approaches to the international personality of NGOs, including the Belgian Law of 1919 and the European Convention on the Recognition of the Legal Personality of International NGOs (INGOs).

\section{NGO Involvement in Global Governance}

Today, NGOs are a visible and active part of international life. They work in a large variety of areas and promote a wide range of aims and goals. The most prominent examples of NGO involvement are found in the fields of human rights, the environment, development assistance, humanitarian aid, peace, edu-

5. See Marianne Beisheim, Nichtregierungsorganisationen und ihre Legitimität, in 43 Aus Polıtik und Zeitgeschichte 21 (1997) [hereinafter Aus Politik und Zeitgeschichte]; Hilmar Schmidt \& Ingo Take, Demokratischer und besser? Der Beitrag von Nichtregierungsorganisationen zur Demokratisierung internationaler Politik und zur Lösung globaler Probleme, in Aus Politik Und Zeitgeschichte, supra, at 12; Thomas Gebauer, ". . . von niemandem gewählt!" Über die demokratische Legitimation von NGOs, in Nichtregierungsorganisationen IN Der TRANSFormation des Staates 95 (Ulrich Brand et al. eds., 2001). 
cation, and family. ${ }^{6}$ NGOs are also active, however, in highly political arenas, such as disarmament and military surveillance, ${ }^{7}$ as well as in what have often been called "non-political matters," such as leisure activities, recreation clubs, or sports associations. ${ }^{8}$ Many NGOs, such as trade unions and clubs, present the views of their members in the international arena and try to advance their specific concerns; others lobby altruistically for public goods (e.g. universal human rights or a clean environment), from which not only members but all human beings will profit. Thus, it is safe to say that NGOs are active across the whole spectrum of international public life.

The most striking issue concerning NGOs, however, is their enormous growth over the last few decades. The Union of International Associations (UIA) in Brussels has registered NGOs in all fields and on all levels since its foundation in 1909. Over the last century, it recorded an extraordinary growth rate for international NGOs. In 1909, the UIA counted 176 NGOs that were active internationally; by the year 2002 it registered $5,936 .{ }^{9}$ This increase is particularly striking at the end of the 1970s and beginning of the 1980s, when the number of NGOs doubled within five years.

Moreover, growth in the number of NGOs in specific sectors of activity is more striking in some issue-areas than in others. The human rights sector currently records the greatest number of NGOs. Since the 1950s, human rights NGOs have remained roughly one quarter of all NGOs, but the total number of human rights groups is five times higher than fifty years ago. The most dramatic development has taken place in the environmental sector. The number of NGOs in the environmental domain increased from two in 1953 to ninety in 1993. That

6. See, e.g., Margaret E. Keck \& Kathryn Sikkink, Activists Beyond Borders: Advocacy Networks in International Politics (1998) [hereinafter Activists Beyond Borders]; Transnational Social. Movements and Global Politics: Solidarity Beyond the State (Jackie Smith et al. eds., 1997) [hereinafter Transnational Social Movements and Global Politics]; Constructing World Culture: International Nongovernmental Organizations Since 1875 (John Boli \& George M. Thomas eds., 1999) [hereinafter Constructing World Culture].

7. See, e.g., Richard Price, Reversing the Gun Sights: Transnational Civil Society Targets Land Mines, 52 InT'L ORg. 613 (1998) (explaining NGOs' involvement in disarmament, specifically land mine removal); Kenneth R. Rutherford, The Evolving Arms Control Agenda: Implications of the Role of NGOs in Banning Antipersonnel Landmines, 53 WoRLd POL. 74 (2000).

8. See, e.g., Volker Rittberger \& Henning Boekle, Das internationale Olympische Komitee-eine Weltregierung des Sports?, 71 Die Friedenswarte 155 (1996); Young S. Kim, Constructing Global Identity: The Role of Esperanto, in Constructing World Culture, supra note 6, at 127.

9. See [2001/02] 38 Y.B. Int'l Org (registering 5, 936 NGOs in 2001/2002). 
means that in the 1950s less than two percent of all NGOs were associated with environmental issues, whereas in 1993 the number of environmental NGOs encompassed around fifteen percent of all NGOs, making the environmental arena the second largest domain in which NGOs are active. ${ }^{10}$

In addition to their numeric growth, NGOs have become increasingly transnational over the years. Many organizations that initially worked only in the domestic frame have gradually extended their activities beyond national borders or have started interacting with intergovernmental organizations. Some founded new branches of the same organization in different states (e.g. Amnesty International, Greenpeace International); others gradually became international as various national groups with similar aims and goals founded an international federative body to coordinate and develop common strategies (e.g. International Federation of Human Rights Leagues, Friends of the Earth International). In response to this increased international coordination of national NGOs, many newly founded NGOs have been established on an international scale from the beginning (e.g. Green Cross International).

The number of NGOs which are now involved in global affairs is similarly impressive. For example, NGO participation in world conferences has greatly increased. More than 840 NGOs participated in the Vienna Conference on Human Rights in 1993;" around 1,400 NGOs took part in the Earth Summit in Rio in $1992 .{ }^{12}$ They did more than participate as outside observers of what was taking place inside the conference rooms: single NGO representatives also sat in governmental delegations and, as advisers, helped to shape the outcome of legal documents. Lately, NGOs have been assisting in supervision of the implementation of the Global Compact, a program among the United Nations, multi-national companies, and non-governmental organizations to improve labor standards, human rights, and environmental protection. ${ }^{13}$

10. Activists Beyond Borders, supra note 6, at 10-11.

11. Laurie S. Wiseberg, The Vienna World Conference on Human Rights, in UNited NATIONs REform: Looking Ahead After Fifty Years 175 (Eric Fawcett \& Hanna Newcombe eds., 1995).

12. Ann Marie Clark et al., The Sovereign Limits of Global Civil Society: A Comparison of NGO Participation in UN World Conferences on the Environment, Human Rights, and Women, 51 WorLD Pol. 1, 9 (1998).

13. See The Global Compact Website, at http://www.unglobalcompact.org/portal; James Paul, Der Weg zum Global Compact: Zur Annäherung von Uno und multinationalen Unternehmen, in DIE PRIVAtisierung der Weltpolitik 104 (Tanja Brühl et al. eds., 2001); see also Ian Hurd, Labor Standards Through International Organizations, 10 J. Corp. Citizenship (forthcoming Summer 2003); SANDrine Tesner \& Georg Kell, The United Nations and Business: A Partnership Recovered 41 (2000). 
Moreover, during the last ten years, many organizations have been seeking regular cooperation with IGOs. These IGOs have in turn established institutional frameworks to regulate their interaction with NGOs. Most importantly, after the series of world conferences in the early 1990s, many NGOs have been granted "consultative status" in the United Nations. From the introduction of "consultative status" in 1950 to the year 2002, the number of accredited NGOs increased from forty-eight to 2,091 organizations. ${ }^{14}$ In addition, many other IGOs (e.g. the Organization for Security and Co-operation in Europe (OSCE) and the Council of Europe) followed the example of the United Nations, incorporating NGOs into their frameworks and establishing directives for cooperation.

Since NGOs have become such significant players in world politics, they are increasingly researched as subjects of legal studies and social sciences. From a legal perspective, different studies have examined the involvement and contribution of NGOs in the formulation and implementation of international laws and norms. In particular, various studies have shown the important role that NGOs can play in the process of establishing new international standards or modifying existing international law according to evolving criteria. Most of these studies have examined the influence of non-governmental representatives on the creation of international law at global conferences. This work has demonstrated how NGOs contribute at all preparatory stages and in the negotiation process with expert knowledge and field experience. ${ }^{15}$

In political science, the increased activity of NGOs on the global scale and their interaction with IGOs, particularly with the United Nations, has been taken

14. Jurij Daniel Aston, The United Nations Committee on Non-Governmental Organizations: Guarding the Entrance to a Politically Divided House, 12 Eur. J. INT'L L. 943, 948 (2001).

15. See, e.g., Joann Schmider, International Conference Diplomacy and the Changing Role of NGOs in International Law, in The Australian and New Zealand Society of International Law: Second Annual Conference 235 (1994); Wendy Schoener, Non-Governmental Organizations and Global Activism: Legal and Informal Approaches, 4 Ind. J. Global Legal Stud. 537, 538 (1997); Dinah Shelton, The Participation of Nongovernmental Organizations in International Judicial Proceedings, 88 Am. J. INT'L. L. 611 (1994); Kevin Stairs \& Peter Taylor, Non-governmental Organizations and the Legal Protection of the Oceans: A Case Study, in The International Politics of The Environment 110 (Andrew Hurrel \& Benedict Kingsbury eds., 1992); Ralph B. Levering, Brokering the Law of the Sea Treaty: The Neptune Group, in Transnational Social Movements and Global Politics, supra note 6, at 225; Julie Mertus, Considering Nonstate Actors in the New Millenium: Touard Expanded Participation in Norm Generation and Norm Application, 32 Int'L L. \& Pol. 537 (2000); Yves Beigbeder, The Role and Status of International Humanitarian Volunteers and Organizations: The Right and Duty to Humanitarian Assistance 92 (1991). 
into account in conceptualizations of international relations. Scholars have widely recognized NGO/IGO links as expanding the channels through which NGOs influence political processes on a global level. ${ }^{16}$ Most importantly, political scientists and sociologists have studied the conditions under which non-state actors have an impact in the transnational sphere. ${ }^{17}$ They have examined the political structures by which IGOs provide opportunities for transnational social movements, ${ }^{18}$ and have identified a "boomerang effect," by which transnational advocacy networks can bypass barriers to their target state by linking up with other states or IGOs, which then put pressure on norm-violating states. ${ }^{19}$

In particular, political scientists have identified NGOs as contributing significantly to the advancement of international standards in the field of human rights protection. Human rights NGOs have continuously gathered information on human rights abuse and put forward proposals regarding the development and implementation of human rights law. By doing this, they influence global public opinion and pressure intergovernmental organizations and individual governments into developing new standards. NGOs have also been directly involved in the drafting processes for various conventions. Experts from Amnesty International and other NGO representatives participated in writing the Convention of the Abolition of Torture ${ }^{20}$ and drafting the Convention on the

16. Seegenerally James N. Rosenau, Turbulence in World Politics: A Theory of Change and Continuity (1990); NGOs, the UN, and Global Governance (Thomas G. Weiss \& Leon Gordenker eds., 1996); The Conscience of the World: The Influence of Non-Governmental Organizations in the UN System (Peter Willetts ed., 1996) [hereinafter The Consci ence of the WorLd]; Florian Furtak, Nichtregierungsorganisationen (NGOs) im politischen System der Europäischen Union. Strukturen, Beteiligungsmöglichkeiten, Einfluß (2001).

17. See Bringing Transnational Relations Back In: Non-State Actors, Domestic Structures and International Institutions (Thomas Risse-Kappen ed., 1995).

18. Kerstin Martens, Applying the Concept of 'Political Opportunity Structures' in European and International Studies, 1 Transnat'l Ass'ss 2 (2001); Jackie Smith et al., Social Movements and World Politics: A Theoretical Framework, in Transnational Social Movements and Global Politics, supra note 6, at 59, 66; Florence Passy, Supranational Political Opportunities as a Channel of Globalization of Political Conflicts: The Case of the Rights of Indigenous Peoples, in Social Movements in a Globalizing World 148-69 (Donatella della Porta et. al. eds., 1999).

19. Activists Beyond Borders, supra note 6, at 12 ; see also The Power of Human Rights: International Norms and Domestic Change (Thomas Risse et al. eds., 1999) (developing the spiral model).

20. See generally Helena Cook, Amnesty International at the United Nations, in The Conscience OF THE WORLD, supra note 16, at 189. 
Rights of the Child. ${ }^{21}$ Similarly, in the field of environmental protection, numerous studies have analyzed NGO input on advancing international standards to protect the environment. ${ }^{22}$

Despite this increasing interest in NGOs, their characteristics have not yet been defined precisely, nor has their status in international affairs clearly been determined. To show the problematic nature of this non-status of NGOs, take the participation of NGOs within the U.N. system as an example: with the everincreasing number of NGOs entering the U.N. system since its opening for national NGOs in 1996, a couple of dilemmas have arisen due to the lack of regulations for NGOs. Most dramatically, the new scheme allows governments to misuse the system of accreditation and promote "their" NGOs to consultative status. As a result, more and more dubious NGOs, so-called GONGOs (government-organized NGOs), from human rights violating states, for example, obtain status and thus have the ability to advocate as "NGOs" in favor of their governments at the United Nations.

These recent developments in the NGO scene have prompted wellrespected internationally operating NGOs such as Amnesty International, Human Rights Watch, and the International Federation of Human Rights Leagues to fear loss of their reputation as credible sources of information and as trustworthy associates. ${ }^{23}$ For example, human rights NGOs can make oral and written statements during the annual six-week sessions of the Commission on Human Rights and present short reports on the human rights situation in a particular country. In recent years, however, more and more GONGOs seek to take

21. See generally Cynthia Price Cohen, The Role of Nongovernmental Organizations in the Drafting of the Convention on the Rights of the Child, 12 Hum. RTs. Q. 137 (1990); Nigel Cantwell, How NGOs Contributed to Drafting the Convention on the Rights of the Child, Paper presented at the Symposium on The Contribution of NGOs to the Formulation and Promotion of International Human Rights Law, May 4, 1990, Geneva (on file with author).

22. See generally Philippe Sands, The Role of Environmental NGOs in International Environmental Law, 2 Development 28 (1992); A. Dan Tarlock, The Role of Non-Governmental Organizations in the Development of International Environmental Law, 68 CHI.-KeNr L. Rev. 61 (1993).

23. Interview with Joanne Weschler, current representative of Human Rights Watch at the United Nations, in New York (Feb. 27, 2001); Interview with Eleni Petroula, representative of the International Federation of Human Rights 1998-2001, in Geneva (Dec. 5, 2000); Interview with lain Levine, representative of Amnesty International 1997-2000, in New York (Feb. 16, 2001); Interview with Loubna Freih, current associate representative of Human Rights Watch, in Geneva (May 30, 2002); Interview with Antoine Madelin, current representative of the International Federation of Human Rights, in Geneva (May 28, 2002). 
the floor in order to give an account of the "wonderful" human rights situation in states well known for human rights violations. Such statements not only reduce the available time for more legitimate human rights NGOs, but also undermine the system of NGO accreditation at the United Nations as a whole. In particular, some Chinese and Iranian organizations have been suspected of being government-organized. ${ }^{24}$

As a result, in recent years, the atmosphere for NGOs, in particular for advocacy organizations, has become significantly less favorable. States that have previously been very much in favor of human rights organizations bringing forward their information and advocating their ideas have lessened or withdrawn their support. ${ }^{25}$ Moreover, access to some parts of the United Nations that had previously been open has been restricted. For example, NGO representatives are no longer allowed to access the delegates lounge, one of the most important places for them to meet informally with state representatives. Additionally, unlike U.N. staff members, NGO representatives now also have to pass through metal detectors before entering some official parts of the United Nations. To many of them, this new practice symbolizes the increasing distrust in NGOs in general. ${ }^{26}$

In short, despite increasing participation in international affairs, the nonstatus of NGOs in the international sphere has created significant problems for them. The most alarming trend is the misuse of the appellation, which calls into question the recognition of NGOs as respected actors on the global level. In the following sections, I will examine the status of NGOs in international law by exploring their recognition by international governmental organizations.

\section{NGO Participation During the League Era}

Originally, the League of Nations did not provide any formal framework for NGO participation. Indeed, the Covenant of the League referred only indirectly to NGOs, by recognizing the work of the International Red Cross. ${ }^{27}$ In

24. Interview with Eleni Petrula, supra note 23.

25. Interview with Iain Levine, supra note 23.

26. See James A. Paul, NGO Access at the UN, at http:/www.globalpolicy.org/ngos/analysis/japaccs.htm (July, 1999).

27. Klaus Hüfner, Nichistaatliche Organisationen, in Handbuch Vereinte Nationen 626 (Rüdiger Wolfrum ed., 1991) reprinted in English in 2 United Nations: Law, Policies and Practice 927 (Rüdiger Wolfrum ed., 1995). 
Article 25, members of the League agreed to advance and promote the foundation and cooperation of national branches of the Red Cross. ${ }^{28}$ Article 24 of the Covenant, however, includes the phrase "all international bureaux" 29 -an expression which leaves open the question whether it refers to other international bodies, such as NGOs, in addition to the Red Cross. ${ }^{30}$

During its first years, the Council of the League allowed for the interpretation of Article 24 broadly as referring to all kinds of international organizations. ${ }^{31}$ Although NGOs did not have formally recognized status at the League, it was often possible for them to propose and advance their standpoints and opinions. ${ }^{32}$ NGOs presented oral reports to League committees, submitted written statements, and participated in discussions. They advised the League on many counts, proposed resolutions as well as amendments to international negotiations, and even sat in official delegations at meetings. The League cooperated

28. The Covenant of the League of Nations, Apr. 28, 1919, Art. 25, reprinted in 1 A History of The League of Nations 43, 61 (F. P. Walters ed., 1952), available at http:/www.worldcourts.com/ pcij/eng/laws/ law01.htm ("The Members of the League agree to encourage and promote the establishment and co-operation of duly authorized voluntary national Red Cross organizations having as purposes the improvement of health, the prevention of disease and the mitigation of suffering throughout the world.") [hereinafter Covenant of the League of Nations].

29. Id. at art. 24 (" 1 . There shall be placed under the direction of the League all international bureaux already established by general treaties if the parties to such treaties consent. All such international bureaux and all commissions for the regulation of matters of international interest hereafter constituted shall be placed under the direction of the League. 2. In all matters of international interest which are regulated by general conventions but which are not placed under the control of international bureaux or commissions, the Secretariat of the League shall, subject to the consent of the Council and if desired by the parties, collect and distribute all relevant information and shall render any other assistance which may be necessary or desirable. 3. The Council may include as part of the expenses of the Secretariat the expenses of any bureau or commission which is placed under the direction of the League.").

30. During the League era, the expression "NGOs" was not commonly used. As will be mentioned later in this paper, this term only arose in the context of the U.N. foundation. In the League of Nations, the term "private organization" was used instead. In the alternative, the expressions "voluntary agencies" or "volas" were also used. Julie Ziegler, Die Beteiligung von Nichtregierungsorganisationen (NGOs) am Menschentechtsschutzsystem der Vereinten NaTIONEN 26 (1998). For clarity of reference in this paper, however, I will continue to use "NGO" when referring to societal actors and their activities during the League era.

31. Borko D. StošiÆ, Les Organisations Non Gouvernementales et les Nations Unies 154 (1964).

32. Peter Schulze, Nicht-Regierungsorganisationen und die Demokratisierung des VN-Systems, in Die Reform der Vereinten Nationen: Die Weltorganisation zwischen Krise und ErNeUERung 126 (Klaus Hüfner ed., 1994); Hüfner, supra note 27, at 928-29. 
with many NGOs on a wide range of issues and in diverse ways. NGOs contributed in various legislative arenas, such as finances, transport, narcotics, refugees, minority rights, mandates, disarmament, women and children, nature, education, and the press. ${ }^{33}$ In fact, a large number of NGOs enjoyed intense cooperation with the League; it is assumed that around 450 international NGOs had contact with the League on a regular and close basis. ${ }^{34}$

NGOs also participated as "assessors" within the League system, a status which varied from commission to commission. ${ }^{35}$ Some NGO representatives sat on League committees and enjoyed all rights and privileges of official representatives, other than the voting right. ${ }^{36}$ On labor issues, NGO participation had been especially intense in the League system. The International Chamber of Commerce occupied three seats on the League of Nations' Economic Consultative Committee, and enjoyed full voting rights and direct participation in League negotiations. ${ }^{37}$ All in all, it can be assumed-as one observer statedthat "the early League attitude towards the private organizations was one of wholehearted cooperation." 38

NGO participation was not limited to the commissions. For example, at the world conference of disarmament in 1932, NGOs made oral presentations directly to the representatives of governments in the Assembly. ${ }^{39}$ NGOs also played an important role in the appointment of Fridtjof Nansen as High Commissioner for Russian refugees. ${ }^{40}$ Every year, the International Federation of League of Nations Society submitted resolutions adopted by the NGOs to the President of the

33. For more historical details on NGOs in the League system, see Steve Charnovitz, Two Centuries of Participation: NGOs and International Governance, 18 MicH. J. INT'L L. 183, 222-37 (1997).

34. Charles Chatfield, Intergovernmental and Nongovernmental Associations to 1945 , in TRANsNational Social Movements and Global Politics, supra note 6, at 25.

35. Dorothy Robins, U.S. Non-Governmental Organizations and the Educational Campaign from Dumbarton Oaks, 1944 Through the San Francisco Conference, 1945, at 38 (1960) (unpublished Ph. D. thesis, New York University) (on file with author).

36. Bill Seary, The Early History: From the Congress of Vienna to the San Francisco Conference, in The Conscience of the World, supra note 16 , at 23.

37. Arlene I. Broadhurst \& Grant Ledgerwood, Environmental Diplomacy Corporations and Non-Governmental Organizations: The Worldwide Web of Influence, 14 INr'L ReL. 8 (1998).

38. Lyman Cromwell White, International Non-Governmental Organizations: Their Purposes, Methods, and Accomplishments 252 (1968).

39. Hüfner, supra note 27 , at 928.

40. ZiEGLER, supra note 30 , at 28. 
Leagues' Assembly. These resolutions were then published in the Assembly's Journal. ${ }^{41}$ NGOs took no part, however, in debates in the Assembly or the Council.

The League system and its relation with NGOs had various effects in the international arena more generally. In particular, it increased the amount of international exchange and coordination. During the League era, many new NGOs and IGOs were established; some of these NGOs were even formed on the initiative of the League. ${ }^{42}$ For example, the International Institute of Statistics, the International Agriculture Coordination Committee, the Joint Committee of the Major International Associations, and the Committee of International Students' Organizations all resulted from the League's efforts for further international exchange. ${ }^{43}$ Other NGOs received financial support from the League. Most importantly, the League gave a grant to the Union of International Associations, enabling it to expand its activities. Relations between NGOs and the League also facilitated international networking. For example, due to their increasing involvement with the League, many NGOs moved their headquarters to Geneva, which in turn led to more contacts among the various NGOs. ${ }^{44}$

Over the years, the League changed its policy concerning formal arrangements with NGOs. In June 1921, the League envisaged patronage for all international organizations, including private organizations, and the Council attempted to incorporate all NGOs on the basis of Article $25 .{ }^{45} \mathrm{~A}$ few years later, however, it withdrew from this position, which had been justified by the desire to guarantee NGOs pluralism and autonomy, ${ }^{46}$ and, despite the large amount of previous interaction with NGOs, the League then cut back relations with them. The first signs of this occurred in 1923, when the League made it clear that the reference in Articles 24 and 25 referred to IGOs only. ${ }^{47}$ The League justified this decision by claiming that it was avoiding the potential risk associated with official supervision of the activity of voluntary organizations. ${ }^{48}$

41. Seary, supra note 36, at 22.

42. Chatfield, supra note 34, at 26.

43. White, supra note 38 , at 248.

44. Chatfield, supra note 34 , at 21 .

45. Id. at 21 .

46. Ziegler, supra note 30 , at 28.

47. Andreas von Weiss, Die Non-Governmentalen Organisationen und die Vereinten Nationen, 27

Zeitschrift für Politik 395 (1980).

48. Seary, supra note 36, at 22; see also StošıE, supra note 31, at 154. 
As a result of the political and economic situation of the time, by the late 1920s and early 1930s, the League had retreated entirely from interaction with NGOs. For example, when the Committee on Social Questions became reorganized in 1936, it remained entirely governmental. ${ }^{49}$ In short, the League shifted from intense interaction with NGOs to minimal contacts with NGOs. As Lyman Cromwell White expressed it, "In general, the interaction between the League and international NGOs changed from one of NGOs supporting and contributing to the policy work of the League to one where the League was less interested in the opinions of NGOs but more willing to provide information for and about them." ${ }^{50}$ Until 1938, however, the League continued to maintain a "Handbook of International Organizations" in which all non-profit organizations were registered."

In contrast to the League of Nations, the International Labor Organization (ILO) maintained a constantly open and interactive relationship with the NGOs, in what one observer called a "democratic" relationship. 52 The constitution of the ILO provided for a tripartite system which encompassed the representatives of workers, employers, and governmental bodies in a relation of one to one to two. ${ }^{53}$ Most importantly, labor and employer representatives had equal status, with the same rights and duties as governmental delegates. ${ }^{54}$ As a result, the workers' representatives had a direct opportunity to influence the policy of the ILO, and the ILO was highly dependent on cooperation with NGOs. As White describes it:

We may conclude that the ILO before the war was an example of an intergovernmental organization largely dependent for its existence on the continued support of one private organization, for it is no exaggeration to state that if the International Federation of Trade Unions had decided to cease cooperation with the ILO, that Organization would have become a lifeless shell, if indeed it had been able to exist at all. The ILO had been conscious of what it

49. Seary, supra note 36 , at 22.

50. Id.

51. Id.

52. White, supra note 38, at 256.

53. Seary, supra note 36 , at 22.

54. White, supra note 38, at 257. 
owes to INGO's and they, particularly the labor and social groups, on the other hand fully realized the great importance to themselves that the ILO continue as a vital, active organization for it embodies their very aspirations. ${ }^{55}$

NGOs also played a vital role at the Permanent Court of International Justice (PCIJ). Unlike its successor, the International Court of Justice (ICJ), the PCIJ allowed for the inclusion of NGOs before the Court. ${ }^{56}$ Contrary to the ICJ, the PCIJ supported the view that the term "international organizations" also applied to non-governmental organizations. ${ }^{57}$ In particular, trade unions and workers' organizations used the opportunity to place their demands before the Court. In 1922, for example, when issues concerning workers' rights were discussed at the International Labor Conference, the PCIJ allowed any organization that expressed the desire to be heard to participate. Similarly, in later cases, employers' and workers' organizations were both involved in proceedings of the PCIJ. Most importantly, international trade unions participated widely in the advisory proceedings of the Court and submitted information to the Court.

55. Id. at 258 .

56. Hermann H.K. Rechenberg, Non-governmental Organizations, in 3 Encyclopedia of Public International Law 614 (1997). Statute of the Permanent Court of International Justice, 1936, art. 66 ("1. The Registrar shall forthwith give notice of the request for an advisory opinion to the Members of the League of Nations, through the Secretary-General of the League, and to any States entitled to appear before the Court. The Registrar shall also, by means of a special and direct communication, notify any Member of the League or State admitted to appear before the Court or international organization considered by the Court (or, should it not be sitting, by the President) as likely to be able to furnish information on the question, that the Court will be prepared to receive, within a time-limit to be fixed by the President, written statements, or to hear, at a public sitting to be held for the purpose, oral statements relating to the question. Should any Member or State referred to in the first paragraph have failed to receive the communication specified above, such Member or State may express a desire to submit a written statement, or to be heard, and the Court will decide. 2. Members, States, and organizations having presented written or oral statements or both shall be admitted to comment on the statements made by other Members, States, or organizations in the form, to the extent and within the time-limits which the Court, or, should it not be sitting, the President, shall decide in each particular case. Accordingly, the Registrar shall in due time communicate any such written statements to Members, States, and organizations having submitted similar statements."), at http://www.worldcourts.com/pcij/eng/ laws/law03.htm.

57. WhITE, supra note 38, at 156; Schoener, supra note 15 , at 546. 


\section{NGOs as "Defined" by U.N. Practice}

The United Nations initially coined the term "NGO" after World War II. NGOs were first officially acknowledged in international law in 1945, with the introduction of the U.N. Charter, whose Article 71 referred to "non-governmental organizations." This arrangement introduced a new standardized form of cooperation between actors in an international society. However, "recognition of their existence has only limited effect and can in no way be regarded as equivalent to a "legal status." 59 In fact, the United Nations introduced a negatively composed term (non-governmental organizations) solely to encompass a variety of actors under one heading, without defining it sufficiently. In the following decades, the term "NGO" has become popular for societal actors of all sorts engaged outside the U.N. framework, and has indeed been increasingly adopted by academics as well as by the activists themselves in this context. ${ }^{60}$ Since the late 1980s, the term "non-governmental organization" (and its respective equivalents) is the prominent word for these types of organizations in most languages; in many German texts the English acronym "NGO," or even the English terminology, can often be found. ${ }^{61}$

58. U.N. Charter art. 71 ("The Economic and Social Council may make suitable arrangements for consultation with non-governmental organizations which are concerned with matters within its competence. Such arrangements may be made with international organizations and, where appropriate, with national organizations after consultation with the Member of the United Nations concerned.").

59. Marcel Merle, A Legal Tangle: The "Status" of Non-governmental International Organizations Between International Law and National Laws, Transnat'L Ass' ns 326 (1995).

60. Scholars first mainly applied the term "NGOs" only when referring to those societal actors which are (due to U.N. criteria) international bodies and engage within the U.N. context. Since roughly the mid-1980s, however, "NGO" became the dominant term for all kinds of societal actors also engaging outside the U.N. system. Before the dissemination of the word "NGOs" solidified through U.N. practice, authors also employed other expressions. For example, they referred to "private organizations" or "international pressure groups." See, e.g., Lyman Cromwell White, The Structure of Private International Organizations (1933); Jean Meynaud, Les Groupes de Pression Internationaux (196i); Peter Willetts, Pressure Groups as Transnational Actors, in Pressure Groups in the Global System: The Transnational Relations of Issue-Orientated Non-governmental Organizations (Peter Willetts ed., 1982).

61. French scholars refer to the French equivalent organisations non-governementales or abbreviate these to "ONG," but in the German context, the situation is more complicated. The official German translation of the 1945 Charter text was nicht-staatliche Organisationen. According to current standards of definitions, however, this term is now seen as being too broad (it translates as "non-state actors"), as it encompasses other actors that are not NGOs (such as multinational com- 
Although Article 71 provides a way for NGOs to enter the U.N. system, it does not define the term precisely. That is to say, it provided only for the U.N. Economic and Social Council (ECOSOC) to consult with "non-governmental organizations" for specific purposes when dealing with matters falling within the competence of the United Nations. According to the United Nations, NGOs are primarily understood as being international bodies, because the article explicitly states that national NGOs are considered only under special circumstances. ${ }^{62}$ In accordance with Article 71 , particular resolutions set out in detail how the interaction between the two types of organizations is regulated. However, these resolutions on the "consultative" relationship between the United Nations and these NGOs focus more, on the principles and objectives of this relationship than on defining precisely the characteristics of NGOs.

Current Resolution 1996/31, which has governed the consultative relationship since 1996, sets forth some general requirements for NGOs (in sections 9 to 13). The United Nations requires some basic organizational principles from its consultative NGOs and, in this context, broadly follows the criteria set up by the Union of International Associations. ${ }^{63}$ That is to say, NGOs must fulfill some organizational criteria, including having an established headquarters, an executive organ and officer, a democratically adopted constitution (providing for the

panies and national liberation groups). The term that is most widely applied now in German works is Nichtregierungsorganisationen. Some authors also simply employ the English term, however. See, e.g., von Weiss, supra note 49 (an early example of such use). Moreover, the English abbreviation "NGO" is commonly used. As a result, in many German studies a "mixed" usage of the German term Nichtregierungsorganisationen and the English acronym "NGO" can be found.

62. U.N. Charter art. 71.

63. The Union of International Associations (UIA) has been most widely recognized in academia and politics for its NGO criteria and database. Over the last few decades, scholars from different countries and backgrounds have referred to the UIA criteria as the fundamental criteria for NGOs. The UIA has set up a number of criteria for NGOs covering the aims, membership, governance, and financing of these organizations. Echoing the original approach of the United $\mathrm{Na}$ tions, the UIA also demands that the aim of these organizations be genuinely international in character. Unlike many other interpretations, the UIA requires that NGOs show their intention of engaging in activities in at least three countries. Moreover, membership must also be drawn from individuals or collective entities of at least three countries and must be open to any appropriately qualified individual or entity in the organization's areas of operation. The constitution of an NGO must provide for a permanent headquarters and make provisions for the members; officers should be rotated among the various member countries in such a way as to prevent control of the organization by one national group. Substantial financial contributions to the budget must come from at least three countries. Moreover, the NGO must be free of the influence of other organizations. See generally The Union of International Associations Website, at http://www.uia.org/. 
determination of policy by a representative body), an authority to speak for the members, and financial independence from governmental bodies. ${ }^{64}$ Furthermore, the United Nations requires the NGOs to fulfill some vague criteria, such as "international standing," "independent governance," and "geographical affiliation." ${ }^{\prime 65}$ For example, NGOs are required to have a recognized standing or be of a representative character within the particular field of their competence, and they should represent large sections of the population. In terms of composition, NGOs may also include members designated by governments if this does not interfere with the free expression of the organization's view. In the current resolution the term NGO also refers to organizations at the national, regional and international level, whereas earlier resolutions-similar to Article 71 -considered only international NGOs. ${ }^{66}$

The consultative status is basically divided into three different categories: general consultative status, special consultative status, and the roster. The criteria for determining which status an NGO receives are similarly vague. General status is reserved for organizations that are concerned with most of the activities of the Council, and from which sustained contribution to the achievement of U.N. objectives can be expected. NGOs in general status must represent major segments of society in a large number of countries in different regions of the world. ${ }^{67}$ The rights and privileges appertaining to this status are the most farreaching of the three categories. NGOs with this status have the right to attend meetings of the ECOSOC and its subsidiary bodies and to speak and circulate statements of 2,000 words. They are even allowed to make proposals for the provisional agenda of ECOSOC or its exercising bodies. ${ }^{68}$

For organizations with a smaller scope of activity, special status applies. ${ }^{69}$ In most respects, special status is similar to general status, except that organizations with special status can neither submit agenda proposals nor speak at meetings of ECOSOC. The written statements of special status organizations are also lim-

64. E.S.C. Res 1996/31, U.N. ESCOR, 49th plen. mtg. II 10, 11, 13, U.N. Doc. E 1996/31 (1996).

65. United Nations, Economic and Social Council, Consultative Relationship Between the United Nations and Non-governmental Organizations III 9, 13, 44, U.N. Doc. E/1996/31 (1996) [hereafter Consultative Relationship].

66. E.S.C. Res 1996/31, supra note 64, II 4, 5 , 9.

67. Consultative Relationship, supra note 65 , I 22.

68. Id. II $28,29,30,31(\mathrm{~d})$.

69. Id. \23. 
ited to 1,500 words.$^{70}$ Other organizations which do not fulfill the criteria for either general or special status, but can make occasional contributions, are put on a list including what are known as roster organizations. ${ }^{71}$ Roster NGOs are limited to attending meetings within their field of competence. The organizations are consulted only at the request of ECOSOC or its subsidiary bodies. Roster NGOs need an invitation by the Director-General to make a written contribution, which is limited to 500 words. ${ }^{72}$

Despite the new resolution, the term NGO remains, as one observer noted, "an awkwardly negative title coined by the United Nations to describe a vast range of international and national citizens organizations, trade unions, voluntary associations, research institutes, public policy centers, private government agencies, business and trade associations, foundations, and charitable endeavors."73 However, Article 71 of the U.N. Charter and other resolutions on NGOs have become a guide for many other intergovernmental organizations both within and outside the U.N. system. For example, the OSCE took it as a model for their relationship to non-governmental actors. ${ }^{74}$ In short, despite the term's inaccuracy, the United Nations created a term to encompass its societal consultants, which then found widespread application. ${ }^{75}$ In the next Part, I will examine whether juridical approaches have been more precise in defining the term NGO.

70. Id. $₫ 37(\mathrm{e})$

71. Id. $\llbracket 24$.

72. Id. I31(e), (f).

73. Angus Archer, Methods of Multilateral Management: The Interrelationship of International Organizations and NGOs, in The US, the UN, and the Management of Global Change 303 (Toby Trister Gati ed., 1983).

74. See Rachel Brett, A New Role for NGOs in the CSCE, in The Challenges of Change: The Helsinki Summit of the CSCE and Its Aftermath 359 (Arie Bloed ed., 1994).

75. Ironically, states also make international commitments regarding NGOs. For example, the United States has to allow transit for the representatives of NGOs under the Headquarters Agreement in Article 71 of the U.N. Charter. U.N. CharTER art. 71. This agreement had been approved by the General Assembly in 1947, and had been signed by the Secretary General and the Secretary of State of the United States. In Section 11, the agreement provides:

The federal state or local authorities of the United States shall not impose any impediments to transit to and from the headquarters district of ... (4) representatives of non-governmental organizations recognized by the United Nations for the purposes of consultation under Article 71 of the Charter... The appropriate American authorities shall afford any necessary protection to such persons while in transit to or from the headquarters district." 


\section{Juridical Approaches to Defining NGOs}

Basically, two major tracks of NGO interpretation can be distinguished: the sociological approach and the juridical approach. Sociological approaches are based on studies of societal actors, and try to capture the term by examining more specifically the composition and functions of NGOs in the transnational arena. ${ }^{76}$ The juridical approach, on the other hand, emphasizes the legal status of NGOs in the national context and the resulting implications for international law. This will be the subject of further inquiry in this section.

States have established conventions and treaties to regulate and define important relations in the international arena. NGOs, however, have not yet been recognized by states as having an international legal personality. Despite several attempts since the beginning of the twentieth century to define NGOs and to codify their legal status, there is not yet any widely adopted international convention on the nature and law of NGOs. At present, there are no regulations under international law governing the establishment, requirements, and the legal status of NGOs. Thus, international law can generally be said to use U.N. criteria for NGOs. ${ }^{77}$

For several decades now, international lawyers and social scientists have placed great emphasis on developing an international codification of NGO status, particularly in France. ${ }^{78}$ Since the beginning of last century, efforts have been undertaken to develop an international order on the subject of NGOs, particularly to release them from the control of the state to which they are legally subordinated. The most important efforts have taken place at the Union of

The Agreement Between the United Nations and the United States of America Regarding the Headquarters of the United Nations, G.A. Res. 169(II), U.N. GAOR, Ist Sess., 101st mtg. at sec. 11, U.N. Doc. A/427 (1947), available at http://www.un.org/depts/dhl/landmark/pdf/a-pvl01.pdf. For the discussion that the Fisher case raised about this question, see generally Yuen-Li Liang, Notes on Legal Questions Concerning The United Nations: The Question of Access to the United Nations Headquarters of Representatives of Non-Governmental Organizations in Consultative Status, 48 AM. J. INT'L L 434 (1954).

76. See, e.g., Anne T. Feraru, Transnational Political Interests and the Global Environment, 28 Int'L Org. 31 (1974).

77. See Charnovitz, supra note 33, at 186.

78. See, e.g., Yves Beigbeder, supra note 15; Les O.N.G. et le Droit International (Mario Bettati \& Pierre-Maris Dupuy eds., 1986); Frits Hondius, La Reconnaissance et la Protection des ONG en Droit International, 2 TRANSNAT'L Ass'ss 2 (2000), available at http:/www.uia.org/uiata/ hondiusfr.htm. 
International Associations and the Institut de Droit International, where scholars have been working on the issue for many decades.

The discussion of the legal personality of NGOs can be traced back as far as 1910, when, at its session in Paris, the Institut de Droit International brought forward a draft convention on NGOs and proposed a study on "the juridical conditions of international associations."79 Others followed the example at another session in Madrid in 1911, and in 1912, a first draft treaty on the international legal personality of NGOs was developed. ${ }^{80}$ None of these attempts, however, led to the establishment of an internationally agreed-upon convention on NGOs.

In 1923, the Institut prepared another draft treaty on the legal status of international associations. Basic requirements for "non-profit private organizations" were to have an international purpose and membership from different countries. In this treaty these associations were defined as "des groupements de personnes ou de collectivités, librement créées par l'initiative privée qui exercent sans esprit de lucre une activité internationale d'intérêt général, en dehors de toute préoccupation d'ordre exclusivement national." ${ }^{81}$ The treaty also provided for an international registration office for associations (which later became the Union of International Associations) and the right of appeal to the Permanent Court of International Justice, the predecessor of the International Court of Justice. Government support for this proposal was not forthcoming, however, and the treaty never came into force. ${ }^{82}$ Several other attempts at NGO treaties had previously failed during the planning period because of the lack of consent of states. ${ }^{83}$

79. Suzanne Bastid, Perspectives d'un Status International pour les Organisations Internationales non Gouvernementales, Summary of paper presented at the Annuaire de l'Institut de Droit International (1952), at http:/www.uia.org/legal/app34.htm (last visited Mar. 6, 2003); see also Charnovitz, supra note 33, at 189.

80. See von Weiss, supra note 47 , at 395 .

81. See Bastid, supra note 79.

82. Charnovitz, supra note 33 , at 189.

83. Beigbeder, supra note 15, at 16-17. Another convention in 1950 (in Bath), also prepared by the Institute, found no allies. Similarly, the 1956 convention on the law of NGOs from The Hague never came into force. This convention applied to foreign companies, associations and foundations. It was originally accepted by the founding members of the European Economic Community in 1968, but never came into force because of the complex problems surrounding the recognition of commercial companies. Dudley Smith, Legal Status of International Non-Governmental Organizations in Europe, Report of the Legal Affairs Committee of the Parliamentary Assembly of the Council of Europe (1985), at http://www.uia.org/legal/app36.htm (last visited Mar. 6, 2003). For more details on NGOs and early International Law, see generally J.J. Lador-LEDerer, International Group Protection: Aims and Methods in Human Rights (1968). 
As a result, NGOs are obliged to accept the national legislation of the state in which they have been established and where they are based. In the Western world, the right to societal organization can be linked back to basic civil rights such as free association or freedom of speech. National laws differ, however, from country to country, and therefore NGO status also varies. Recognition, rights, and duties depend on the respective national conditions. In particular, national juridical systems differ in terms of tax regulations for societal associations and the criteria for official recognition. ${ }^{84}$

Because of these differences in national laws, issues arise for NGOs in the international sphere. For example, difficulties arise when the activity of an NGO transcends the borders of its state of origin. An internationally operating NGO with branches in several states would fall under different national systems of law. At the same time, NGOs cannot evade national jurisdiction when they are participating at the international level, since some IGOs, including the United Nations, require that NGOs have a certain legal status when applying for "consultative "status. ${ }^{85}$

Only Belgian law recognizes internationally-operating NGOs as having a "preferential status," even when their headquarters are located outside Belgium. ${ }^{86}$

84. For example, some countries, such as the United Kingdom and the United States, have an advantageous charity law for societal associations. Most countries, however, do not allow for these differences in taxes. In Germany, favorable tax provisions can be used by organizations whose objective is acknowledged to be of common interest. Germany also has a special right for foundations, while other countries do not. For example, Amnesty sections in the United States and Germany enjoy tax-exempt status, but in the United Kingdom these sections do not qualify as a charity. Spain and Belgium do not differentiate between charities and other forms of societal activism. Moreover, it is compulsory for "friendly societies" and "charities" in the British Isles to be registered (unless they are clubs); while the right to be an "eingetragener Verein" in Germany is optional. In Denmark, associations have no duty of notification or registration; in other states, it is compulsory for the granting of legal personality. In Denmark, France, Ireland, the Netherlands, and the United Kingdom, all inhabitants have the right to form associations; in most other countries this right is reserved for national citizens. In Greece, it takes a minimum of twenty people to form an association, in Germany only seven people are needed and in Luxembourg and Belgium, three persons are sufficient. In France, only registered organizations have the right to bring legal proceedings to court; in Germany, Great Britain, Denmark and Italy, official registration as a societal organization is not needed. Nicole Fontaine, Report on Non-Profit Making Associations in the European Community, Explanatory Statement accompanying report on behalf of the Committee on Legal Affairs and Citizens' Rights of the European Parliament If 21 (1986), at http:/ www.uia.org/ legal/app37.htm (last visited Mar. 6, 2003); see also Lester M. SAlamon, America's Nonprofit Sector (2d ed. 1999).

85. Rechenberg, supra note 56 , at 617.

86. Paul Ghils, International Civil Society: International Non-Governmental Organizations in the International System, 133 InT'L Soc. ScI. J. 417, 419 (1992). 
The Belgian model of 1919 is still the most important text in the law of NGOs. ${ }^{87}$ In Article 8 it states, "International associations with their registered office abroad which are governed by a foreign law ... may in Belgium ... exercise the rights accruing from their national status. It is not essential that the administration shall include at least one Belgian member." In practice, this means that Amnesty International, with its headquarters in London, comes under British law, whereas the International Federation of Human Rights, based in Paris, has to fulfill French requirements.

Even Belgian law is unsatisfactory, however, since it only recognizes the particular national law to which the international NGO in question is subject. As Marcel Merle argued:

The unilateral granting of preferential status, even if combined with facilities to NGOs established in other countries, solves only part of the problem of the functioning of NGOs. In the most developed version ... national legislation can go so far as to recognize, within the national territory, the validity of activities whose origin is outside their frontiers but it cannot and will never be able, without the consent of foreign states, to control those same activities beyond the limits of national territory. ${ }^{88}$

Within the international law context, some progress in the codification of NGO personality has been made on a regional level. Only the European Convention on the Recognition of the Legal Personality of International Non-Governmental Organizations can be considered an international agreement on NGOs. It provides for the general recognition of the legal personality of an NGO in any state that is party to the convention. This convention was adopted in 1986 and came into force in 1991. Today, eight countries are party to the Convention. The European Convention, however, simply follows Belgian law and

87. Status of International Associations under Belgian Law, at http:/www.uia.org/legal/ app61.htm (last visited Mar. 6, 2003). The status of international associations under Belgian Law of October 25, 1919 was first limited to international associations with "scientific objectives." This restriction was modified by the law of December 6, 1954 which extended the status to international associations with "philanthropic, religious, scientific, artistic or educational objectives." Id.

88. Marcel Merle, International Non-Governmental Organizations and their Legal Status, Paper presented at the "Colloquy on the role of international non-governmental organizations (NGOs) in contemporary society," (1983), at http://www.uia.org/legal/app35.htm (last visited Mar. 6, 2003). 
recognizes the national law of the respective state in which the NGO has its headquarters. ${ }^{89}$ As such, it is still not a convention that enables NGOs to have an international personality; the main difference, however, is that "every INGO carries with it its identity and its status without having to request new recognition from the various countries on its activities." ${ }^{\prime 0}$

Thus, NGOs must have been established under the internal law of one of the states party to the convention and must have their statutory office and central headquarters in the territory of one of the state parties as well. The Convention is limited to international NGOs, defined by an "aim of international utility" and operation in at least two states. Thus, the European Convention takes up the conditions and the constraints of Belgian national law on NGOs. In fact, as one observer has argued, the European Convention can even be interpreted as a step backwards on the international personality of NGOs. Merle observed "that the 'downgrading' of the status of INGOs by purely and simply placing them on the same basis as national associations in their host country would only partly meet the desires of those concerned." ${ }^{\text {11 }}$

\section{Conclusion}

From a legal perspective on international affairs, NGOs seem to remain terra incognita. A historical analysis of NGO perception in international law demonstrates that the question of international personality of NGOs has not yet sufficiently been answered. Paradoxically, while states have increasingly incorporated NGOs into structures and procedures of global governance, it remains unclear what characterizes NGOs and what status they officially have under international law. Although states welcome NGO contributions to international negotiation processes and have granted "private associations" some recognition at the national level, they have not yet agreed on a standard for NGOs operating in the transnational sphere.

89. See The European Convention on the Recognition of the Legal Personality of International Non-Governmental Organizations, opened for signature Apr. 24, 1986, Council of Europe, art. 2, reprinted in Coljcil of Europe, Explanatory Report on the European Convention on the Recognition of the Legal Personality of International Non-Governmental Organizations I 4 ( 1986 ) ("The legal personality and capacity, as acquired by an NGO in the Party in which it has its statutory office, shall be recognized as of right in the other Party.").

90. Merle, supra note 59, at 328 .

91. Id. at 325. 
The analysis of rules and regulations over the last century has revealed that international law on the status of NGOs remains significantly underdeveloped. The rights and duties of NGOs under the U.N. Charter do not differ much from the League system. More effort has been put into regulating the relationship between NGOs and other actors, such as the United Nations, than into setting standards for NGOs. Moreover, international agreements on the legal personality of NGOs seem to advance only slowly. Thus, during the last century, not much progress has been made; the European Convention of 1986 does not differ much from Belgian law on NGOs from seventy years earlier. NGOs are only indirectly recognized through other sources of international law that envisage a role for them, as in the Millennium report. ${ }^{92}$

In sum, whereas NGOs increasingly take part in advancing international legal standards on a variety of issues, the status of NGOs in international law has not yet progressed. Considering the growing number of NGOs participating in international life and the evolving role they play in negotiation processes, it is astonishing that it is still unclear how to characterize an NGO in legal terms. NGOs are often invited to take part in international affairs because they are seen as "representing civil society" and, as such, their participation is interpreted as legitimizing or democratizing the whole process. Taking into account, however, that some states take advantage of this situation and select, appoint, or support specific government-friendly NGOs, the necessity for international standards becomes important. In addition, it is in the interest of NGOs to maintain their "pure" image, because otherwise the representativity of NGOs-and thus their raison d'être-could be called into question.

92. Millenium Report, supra note 3; see also Michael Hempel, Die Völkerrechtssubjektivität internationaler nichtstaatlicher Organisationen (1999). Hempel refers to Article 48 of the European Convention on Human Rights, which acknowledges NGOs' right to bring accusations to the court and as such indirectly recognizes the international personality of NGOs. See Convention for the Protection of Human Rights and Fundamental Freedoms, May 6, 1963, Council of Europe, art. 48, reprinted in Gordon L. Weil, The European Convention on Human Rights: Background, Development, and Prospects App. II (1963). 